\title{
The long after-life of Christopher Wren's short-lived London plan of 1666
}

\author{
Michael Hebbert \\ Bartlett School of Planning, UCL \\ <m.hebbert@ucl.ac.uk> \\ ORCID 0000-0003-1348-0595
}

\begin{abstract}
Immediately after the 1666 Great Fire, Christopher Wren sought to persuade King Charles II to rebuild London according to the best principles of baroque urbanism, with wide straight streets, axial symmetry, monumental endpoints, and a waterfront with open quays. The plan was quickly rejected as impracticable and Wren's creative energy went into the design of St Paul's Cathedral and more than fifty parish churches. But his scheme was memorialised by his son and grandson as a scandal of lost opportunity, a noble vision 'unhappily defeated by faction'. Widely reproduced by print-makers, it gained iconic status, influencing street improvement in eighteenth century London, nineteenth century public health reform, late-Victorian advocacy of municipal autonomy, and twentieth century planning controversies including the Paternoster Square redevelopments of 1955 and 2000. The paper shows how archival research disproving the received narrative of Wren's plan opened the way for different understandings both of the planning legacy of reconstruction after the Great Fire, and of his own accomplishments as a Renaissance architect working within a mediaeval street plan.
\end{abstract}

This is the Author's Original Manuscript of an article published by Taylor $\&$ Francis in Planning Perspectives in 2019 available online: https://doi.org/10.1080/02665433.2018.1552837 
The Great Fire of London was a catastrophe that razed three quarters (117 hectares) of the ancient city in September 1666. Ten years later a monumental column, the world's tallest, was erected where the fire had broken out. It commemorates the disaster but also conveys the intellectual creativity of the era, and the politics of Restoration monarchy. Designed by Sir Christopher Wren and Robert Hooke, both scientific members of the Royal Society, it carries a nine foot gilded copper ball of fire with an aperture allowing the shaft to be used as a gigantic zenith telescope for astronomical observation. Earlier options included a blazing urn, a phoenix with wings outstretched and a fifteen foot statue of King Charles II, like the smaller pillar erected to Lord Nelson in Trafalgar Square almost two centuries later ${ }^{1}$. The King himself decided in favour of the neutral ball at the summit. However at street level the Monument's iconography was unambiguously Royalist (figure 1). A magnificent bas relief by Caius Cibber on the west face of the plinth portrays the King accompanied by allegorical figures of Science, Architecture, Liberty, Justice, Victory, handing a scroll to an exhausted damsel. She represents the City of London and is supported by Time, Manual Skills and Industry. The figures of Plenty and Peace hover overhead, Envy is imprisoned below. As in the contemporary portrayals of Louis XIV in the triumphal arches erected at the Porte St Martin and Porte St-Denis in Paris, the Monument celebrates the monarch as classical hero rescuing a submissive fallen city.

\footnotetext{
1 Moore, "The Monument"
} 


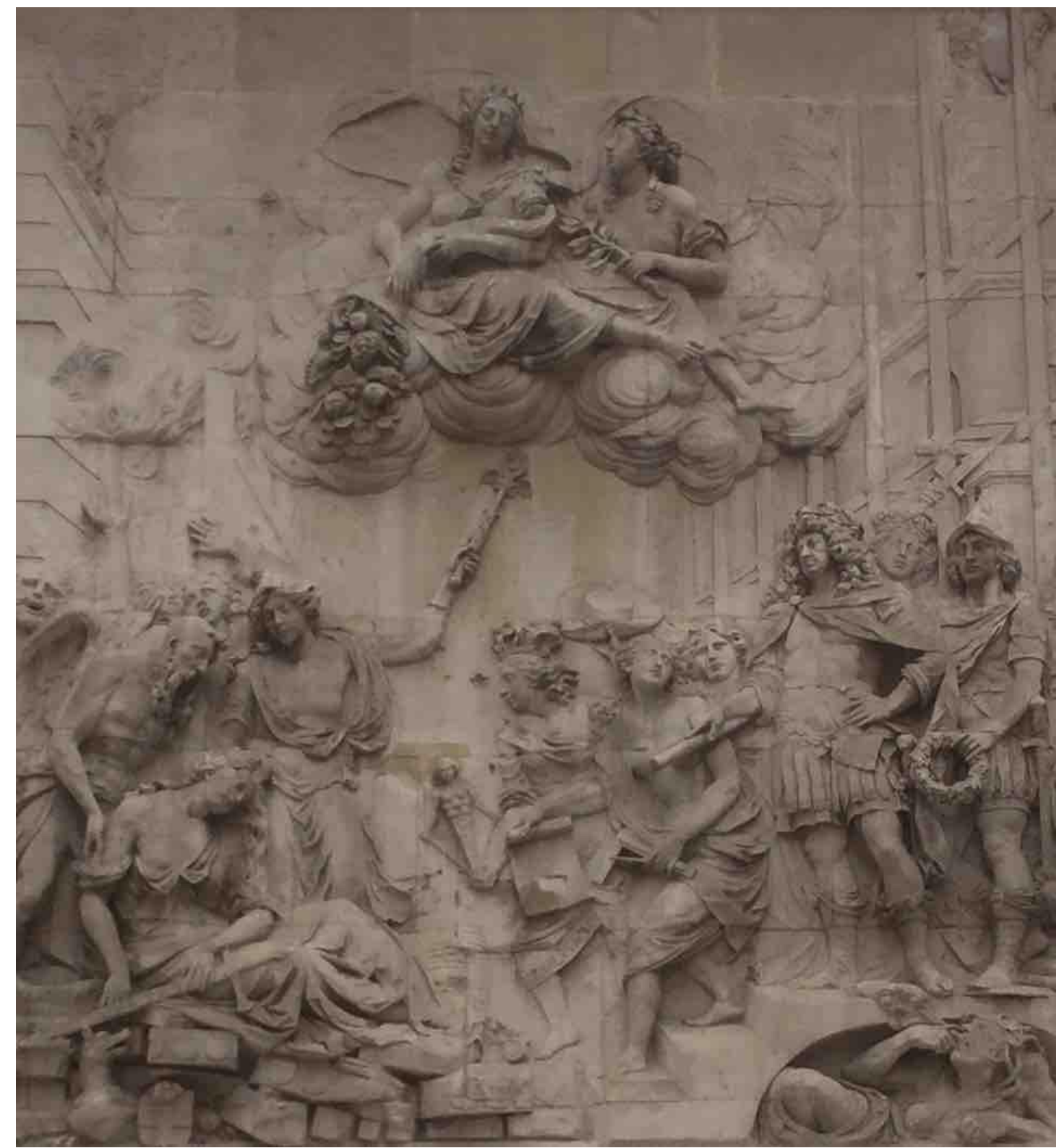

fig.1 King Charles II as London's saviour; Caius Cibber's bas-relief on west face of the plinth of the Monument. London. Photo credit: author.

The role of monarchy in post-Renaissance urban transformations has been much discussed by historians of city planning ${ }^{2}$. Within the enceinte of artillery fortifications, cities were being remodelled by their rulers with symmetrical layout, straight streets, regular building plots and an enlarged public realm. Such Baroque reordering reflected the requirements of mercantilist circulation and

${ }^{2}$ Konvitz Urban Millenium, Morris History of Urban Form ch.6, Mumford City in History ch.13 
standing armies but its concern for architectural unity was also ideological, transforming urban space into a theatre of kingly power. The Stuart dynasty had always appreciated the potential of urbanism to project their absolutist conception of monarchy. Before the Civil War Charles I had designated Inigo Jones as Royal Commissioner for Buildings in an attempt to impose order on the metropolis ${ }^{3}$. His son Charles II continued the campaign after the Restoration, and his 1662 Act for widening street bottlenecks and preventing frontage encroachments in London and Westminster (14 Charles II.c2) would provide important legal precedents for reconstruction after the Great Fire. The superior effectiveness of French city planning was a common topic in court circles. Walter Besant quotes Sir William Davenant's satirical portrait of London in 1663:

'Sure your ancestors contrived your narrow streets in the days of wheelbarrows, before those greater engines, carts, were invented. Is your climate so hot, that as you walk, you need umbrellas of tiles to intercept the sun ? . . Is unanimity of inhabitants in wise cities better exprest than by their coherence and uniformity of building: where streets begin, continue and end in like stature and shape ? But yours (as if they were raised in a general insurrection, where every man hath a several design) differ in all things that can make distinction' ${ }^{4}$.

John Evelyn was the most outspoken and prolific advocate of change. His State of France (1651) contrasted London's poor nasty cottages with the fair and uniform streets of Paris 'where you would imagine yourself rather in some Italian Opera,

\footnotetext{
3 Morris History of Urban Form p.214
}

${ }^{4}$ Besant London p.240 
where the diversity of Scenes surprise the beholder than believe yourself to be in a reall citie' 5. His Character of England (1659) was written in the guise of a French traveller reporting home in horror at the ugliness and confusion of this 'resemblance of hell upon earth' with its narrow unpaved streets and malicious overhead spouts and gutters ${ }^{6}$. His Fumifugium (1661) included a proposal to equip London with river quays to match those of Bordeaux and Paris. Soon after its publication the king asked him to prepare a Parliamentary bill to implement the proposals ${ }^{7}$. As a known advocate for monarchical transformation of urban space, Evelyn's London Revived (1666) urged Charles II to act on the opportunity provided by the Great Fire ${ }^{8}$. He presented a reconstruction plan to the king within a fortnight of the disaster - but found that his younger friend, Dr Christopher Wren, Savilian Professor of Astronomy at Oxford, had beaten him to it by three days.

Wren was, like Evelyn, a polymath. In transition from early success in mathematics and astronomy to his subsequent fame as an architect, he was ambitious to secure building commissions under royal patronage. He had travelled to France in 1665 expressly to pursue this interest, spending several months around the Louvre Palace, which he described as the best school of architecture in Europe ${ }^{9}$. He studied the ordered classical facades of the Place Vendôme, the axial symmetry of the Tuileries and its projected westward extension (the future Champs Elysées),

\footnotetext{
${ }^{5}$ Rosenau Social Purpose p.38

${ }^{6}$ Upcott Evelyn

${ }^{7}$ Uglow Gambling Man p.234

${ }^{8}$ Evelyn London Revived

${ }^{9}$ Wren Society Vol XIII (1936) p.40
} 
the first of the Parisian grands boulevards along the line of the old city walls, the avenues and rond-points of Versailles, the broad quaysides of Bordeaux. One of his visitors in the autumn of 1665 was Edward Browne, son of Sir Thomas Browne, who had reported home on his good company:

'I asked him which hee took to bee the greatest work about Paris, he said the Quay or Key upon the river side, which he demonstrated to me to be built with so vast expanse and such great quantity of materials that it exceeded all manner of ways the building of the two greatest pyramids in Egypt' 10.

While at the Louvre Wren briefly met Gianlorenzo Bernini, designer of the great symmetrical piazza in front of St. Peter's. It was with such images in mind that he returned to London in the summer of 1666.

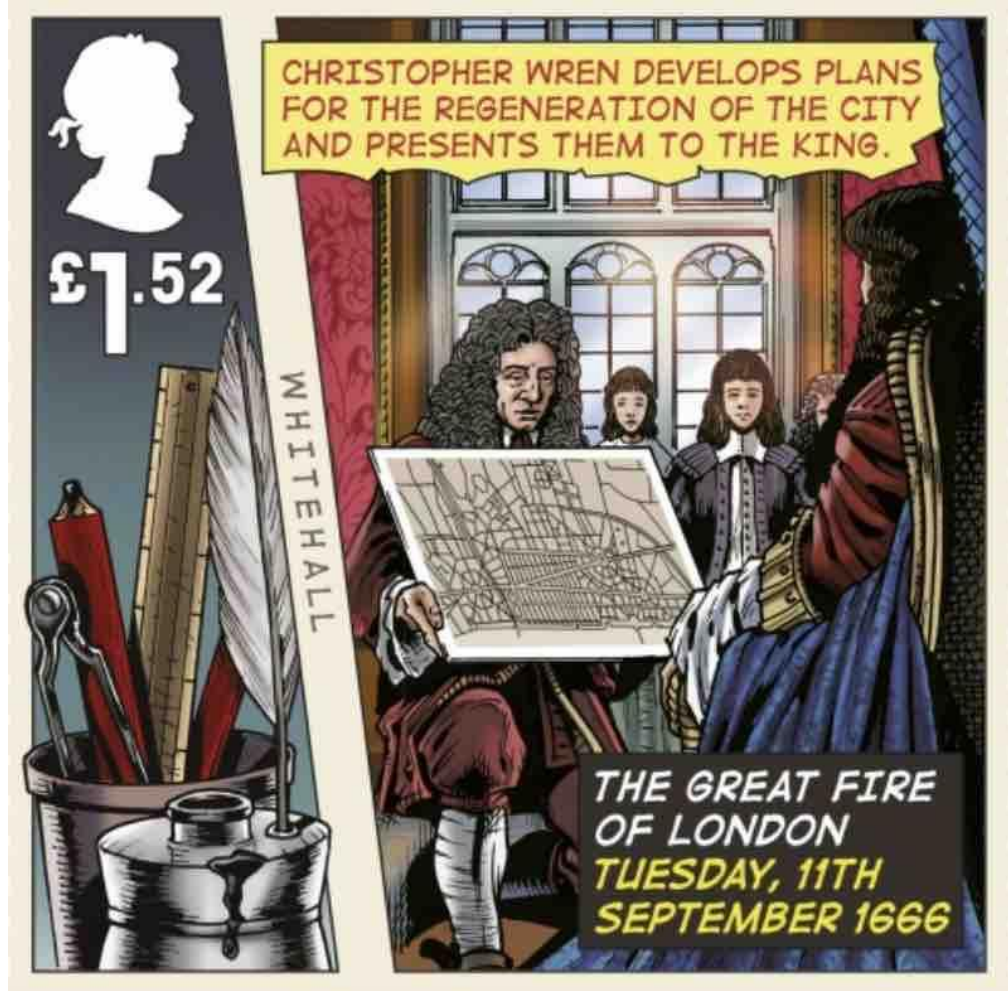

fig.2 Christopher Wren presents his plan to the King on September 11th 1666 (Royal Mail $£ 1.52$ stamp issue, September 2016). Photo credit: author

${ }^{10}$ Jardine Grander Scale p.246 
The catastrophic fire burnt from Sunday September 2nd to Thursday September 7th 1666. Being quicker off the mark than his friend Evelyn, Wren presented his plan to the King on Sunday September 10th, an event commemorated 350 years later in a postage stamp (figure 2). His drawing has the distinction of being, as Cecil Stewart observes, the very first Renaissance plan for an English city ${ }^{11}$, and though it drew on the precedents of Rome and Paris, its proposed remodelling went further than either. ${ }^{12}$ The original preserved in the Codrington Library of All Souls College Oxford, measures $271 / 2$ " by 13 " and is drawn to a scale of 140 yards to the inch (figure 8 below). ${ }^{13}$ In its echoes of the Roman forum as reconstructed by Palladio and its application of Vitruvian theory, the design displayed Wren's classical learning as well his familiarity with the latest Continental practice. ${ }^{14} \mathrm{He}$ accompanied his two-dimensional plan with a vivid written description of a walk though the future townscape. Henry Oldenburg, closely watching developments to ensure (as its Secretary) that the Royal Society got due credit from the activity of its scientific members, reported that the King had 'manifested much approbation'. ${ }^{15}$ After Wren and Evelyn had submitted their reconstruction schemes in court, others followed from Robert Hooke and Richard Newcourt. A submission from Captain Valentine Knight proposed construction of a new canal around the city, enabling the Crown to take financial advantage of the disaster: this impolitic suggestion was rewarded by imprisonment in the Tower of London.

\footnotetext{
${ }^{11}$ Stewart Prospect p.96

12 Abercrombie "Wren's Plan" p.71

${ }^{13}$ Geraghty, Architectural Drawings, catalogue nos. 394-6

${ }^{14}$ Geraghty, Architecturak Drawings, p.256

${ }^{15}$ Oldenburg to Boyle, Wren Society, XVIII (1941) p.197
} 


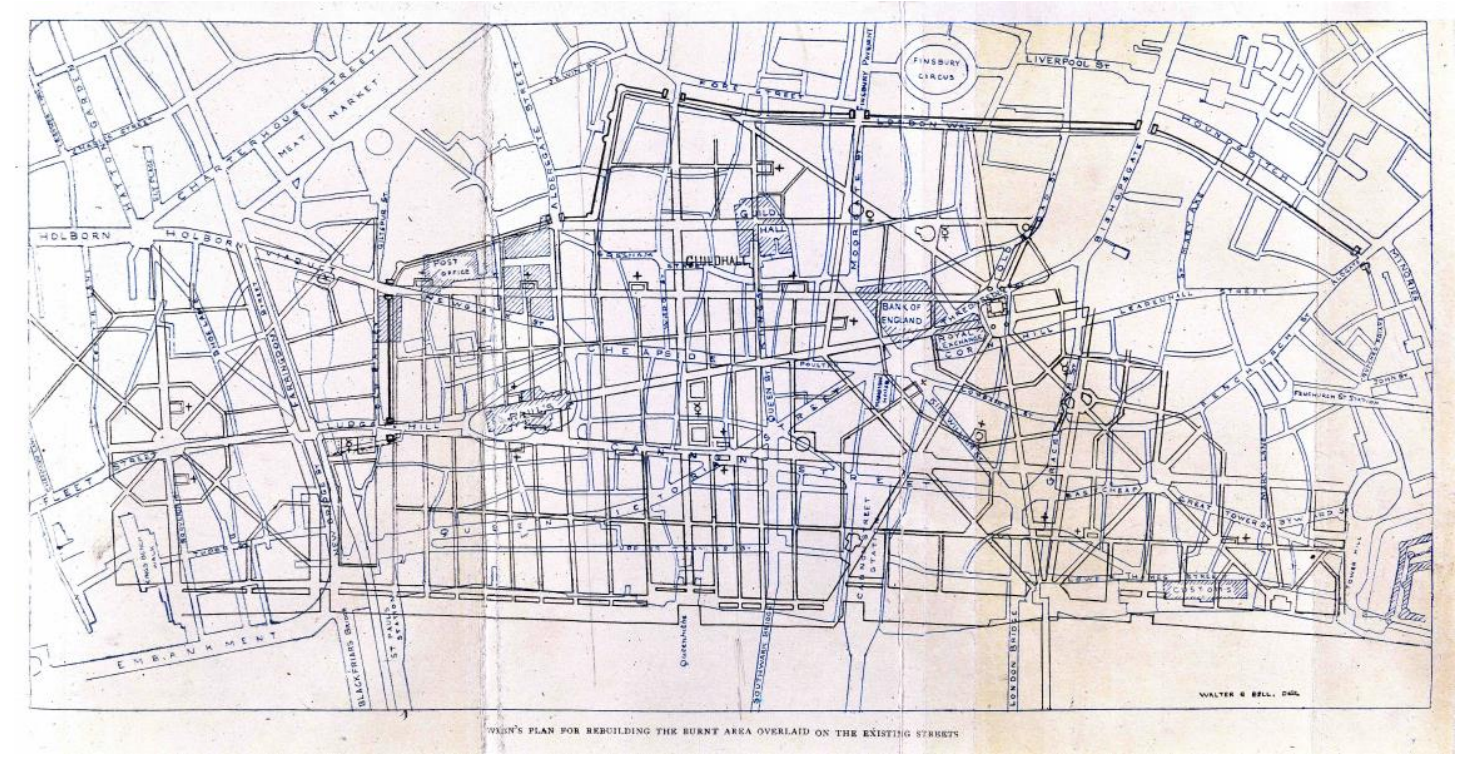

fig.3 Christopher Wren's plan overlaid on the previously existing street map, as drawn by Walter G. Bell Great Fire in 1920. Photo credit: UCL Media Services

In its combination of radial axes and gridded morphologies, Wren's was the most sophisticated of the plans for the rebuilding of London. ${ }^{16}$ Writing to Robert Boyle on September 18th 1666 Oldenburg praised the conception yet questioned whether it had sufficiently 'consulted with the populousness of a great city'.17 Without the benefit of an accurate base-map, Wren's reckoning was incorrect in several aspects. Not one of his streets matched existing alignments and implementation would have involved redefining every single property title, an impossible cadastral undertaking (figure 3). John Summerson summarised the situation well:

'His celebrated plan, sketched out while the ruins smoked, was a hypothetical project, produced without taking into consideration the economic urgency of the situation, which demanded that the thread of city

\footnotetext{
${ }^{16}$ Abercrombie "Wren's Plan"

17 Oldenburg to Boyle, Wren Society, XVIII (1941) p.198
} 
life be resumed as soon as possible and as nearly as possible on the old lines'. ${ }^{18}$

The monarch was, by definition, the client whom Wren sought to inspire, but with Civil War and the execution of Charles I fresh in political memory the constitutional position of British royalty was very different from that of Louis XIV, Le Roi-Soleil. Charles's powers were constrained by Parliament and his financial room for manoeuvre limited by the demands of the ongoing Anglo-Dutch war, which in turn depended on loans from the commercially-minded burghers of the City of London, who had a strong sense of their historic liberties and entitlements. As Oldenburg correctly predicted to Robert Boyle a month after the fire, 'the great stress will be how to raise money for carrying on the war and rebuild the city at the same time' ${ }^{19}$. After the eery emptiness of the ruins through the winter of 1666 the King and the City were of a single mind that the overriding priority was commercial revival.

Some Members of Parliament did speak in favour of radical street plans when the Commons debated reconstruction on September 27th and 28th but more favoured a pragmatic rebuilding on existing property lines. ${ }^{20}$ Though the topic of new alignments did not definitively disappear from the agenda of London's six Rebuilding Commissioners until mid-October 21 the template for reconstruction had been set more than a month earlier by Charles II's Declaration to his City of

\footnotetext{
${ }^{18}$ Summerson Georgian London p.?

19 Oldenburg to Boyle, Wren Society, XVIII (1941) p.198

${ }^{20}$ Hibbert London, the Biography; Tinniswood By Permission of Heaven.

${ }^{21}$ Reddaway The Rebuilding p49
} 
London Upon Occasion of the Late Calamity by the Lamentable Fire of September 13th, in which he promised to rebuild the Custom House both expeditiously and in situ, 'in the place where it formerly stood, and enlarge it with the most convenience for the merchants that can be devised' 22 .

The Monument was initiated in 1771 and completed for the tenth anniversary of the Fire in 1776. The inscription on its south face recalls the belief that it would take an age to rebuild London, but instead just three years had brought a revival as splendid as it was speedy :

\section{UNUM TRIENNIUM ABSOLUIT QUOD SECULI OPUS CREDABATUR}

\section{RESURGIT LONDINUM MAIORI CELERITATE AN SPLENDORE INCERTUM}

The Latin inscription incorporates a subtle reference to Tacitus's observation that the burning of Rome might have been caused by chance or by the malice of Emperor Nero (forte an dolo principis incertum) ${ }^{23}$. Charles II, by contrast, had facilitated and supported recovery. Thus, the scroll he bestows on London in Cibber's bas-relief is not Wren's plan but the Act for the Rebuilding of the City of London, signed into law on February 8th 1667. London was rebuilt through regulatory technique rather than imposition of a master plan. Existing street alignments were respected but widened to meet four standard profiles, depending on their traffic levels, ranging from river quays of 100 feet to alleys of a minimum width of 16 feet (later reduced to 14). ${ }^{24}$ Stalls, penthouses, jettied overhangs, lowhanging trade signs and other obstruction were banned. The Act fixed standards

\footnotetext{
22 Jardine On a Grander Scale p267

${ }^{23}$ Moore "The Monument" p509

${ }^{24}$ Morris History of Urban Form, p.221
} 
for fireproof construction and set up a durable institutional framework of surveyors and commissioners to monitor them. Where land was taken for street widening compensation was paid at five shillings the square foot. To finance the rebuild, the Act levied a temporary duty of one shilling a ton on London's coal imports; three years later the term of this carbon tax was extended indefinitely and its rate tripled.

Recent research has highlighted the role of applied science in the reconstruction process. Of the six members of the Reconstruction Commission three (including Sir Christopher Wren, knighted in 1673) were appointed by the Crown and three (including Robert Hooke, Professor of Geometry at Greshams College) by the City. For six or seven years Hooke combined experimental science at Greshams and the Royal Society with daily field-work through the fire-damaged area, surveying streets, staking out frontage lines, measuring property boundaries, issuing foundation certificates, and calculating compensation to owners. Widening, levelling and regrading the City's entire existing stock of streets was a task of immense technical complexity 25 : small wonder Hooke regarded it as an integral part of his scientific work. ${ }^{26}$

Though the process of cadastral recertification was never fully completed, it accelerated the development of scientific survey and cartographic techniques. William Leyburn's survey work on behalf of the Commissioners enabled John Ogilby to publish his Large and Accurate Map of the City of London in December

${ }^{25}$ see Besant London, app. V-VI

26 Cooper Robert Hooke p.123 
1676, just after the completion of the Monument, and William Morgan to follow with a more detailed and elaborate map in $1682 .{ }^{27}$ As the first large-scale ichnographical ground plots of any major city these maps marked a very significant milestone in urban cartography. ${ }^{28}$ But their content revealed a morphology very different from that envisaged in Wren's master plan. Only two fragments had been implemented: King and Queen Streets, opening a direct line from the Guildhall to the river; and canalisation of the River Fleet from Blackfriars up to Farringdon. The New Canal, as it was known, survived for navigation just fifty years before being covered over, and its quays were under encroachment from the outset. In premature expectation John Ogilby's map of 1676 showed buildings set back forty feet behind open quays and landing spaces all along the north bank of the Thames. ${ }^{29}$ But it was never to be. The City as so rapidy rebuilt was - in Sir John Summerson's words - 'a mediaeval growth crystallised in Stuart and Georgian brick' 30 .

\footnotetext{
27 Hyde $A$ to $Z$

${ }^{28}$ A point regrettably missed by Hebbert "Figure-ground" p.708

${ }^{29}$ See Peter Barber's introduction to Saunders A to Z, pp.1-4

${ }^{30}$ Summerson Georgian London p.39
} 


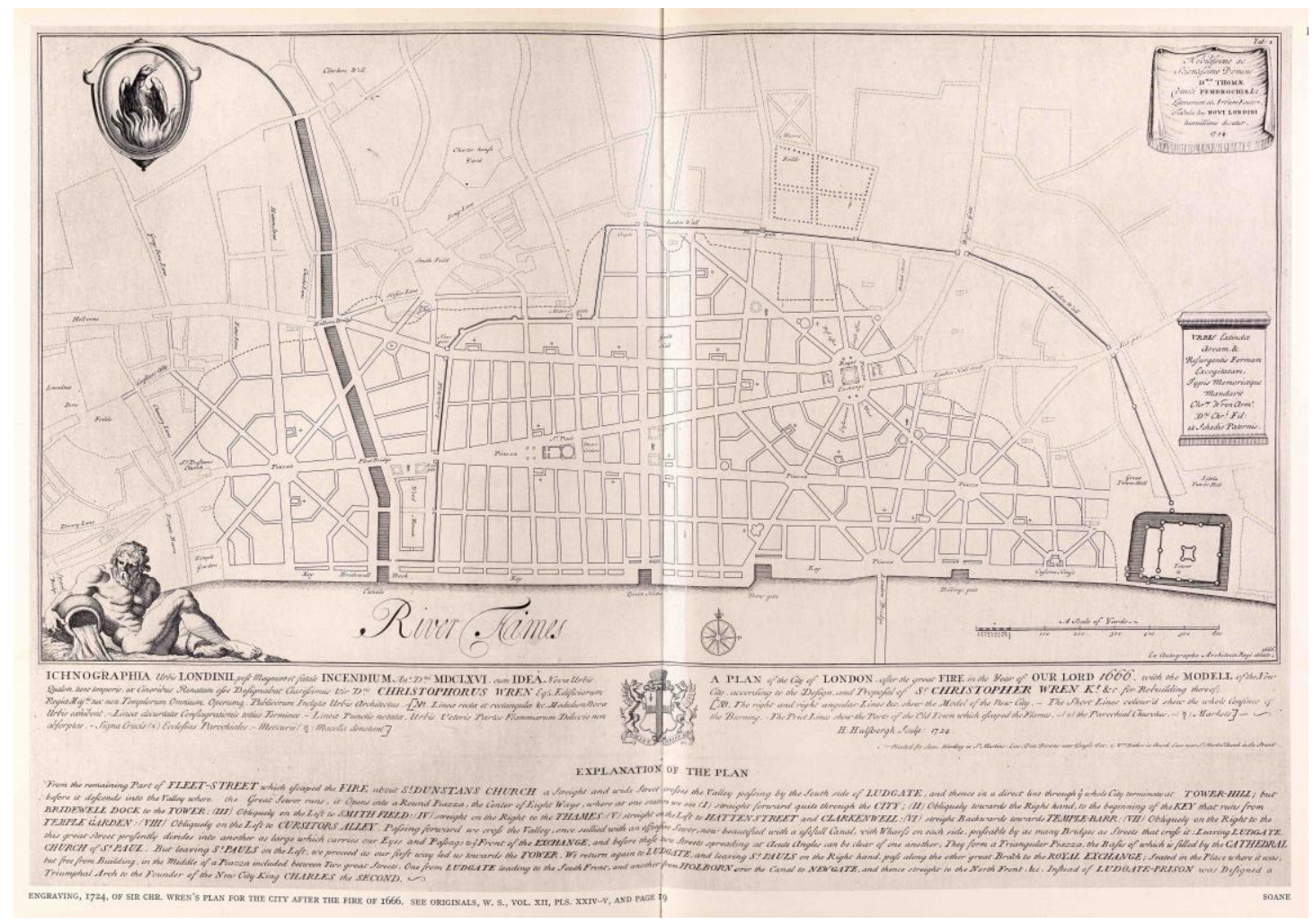

fig.4 Engraving, 1724, of Sir Chr. Wren's Plan for the City After the Fire of 1666. From Wren Society Volume XVIII (1941) plate XVI. Credit: UCL Digital Media Unit

\section{Birth of a Myth}

Thus London and Paris presented a contrast in the late seventeenth century: the French capital was beginning to be shaped geometrically by the King's architects Jules-Hardouin Mansart and André le Nôtre, while London's experience of Baroque urban layout was limited to new squares projected in the suburbs by private landlords. In such a context Wren's unimplemented plan remained potent as a counterfactual. His son Christopher had the map engraved, printed and published in 1710 and again in 1724 (figure 4). ${ }^{31}$ His assistant Nicholas Hawksmoor referred to the plan repeatedly as an example of the superiority of

${ }^{31}$ Wren Society, Vol XVIII (1941), plate XVI 
French urban design, or as he colourfully called it 'Police Architectonical'. He wrote to George Clark in 1715:

'When London was Burnt in 1666 out of that fatal accidentall mischief one might have expected some good when ye Phoenix was to rise again, viz. a convenient regular well built City, excellent, skillful, honest Artificers made by ye greatness and Quality of ye worke in rebuilding such a Capital. But instead of these we have noe City, nor Streets, nor Houses but a Chaos of Dirty Rotten Sheds, always Tumbling or taking fire, with winding crooked passages - scarce practicable - Lakes of Mud and Rills of Stinking Mire Running through them'. 32

Daniel Defoe repeated this critique of squandered opportunity in his Tour through the Whole Island of Great Britain of $1724^{33}$ and it was reiterated by Hawksmoor in his oration to the opening ceremony of the Royal Hospital at Greenwich in 1728. Once again he praised the late King Louis XIV and his 'Admirable Minister Monsieur Colbert' for bringing honour and profit to France by rectifying the irregular and ill management of cities by their attention to Police Architectonical. 'How useful had the cultivating of the Science of Architecture been, at the rebuilding of the City after the dreadful Fire in Anno 1666, if the Citizens would have been Capable of Advice, and pursued the Plan laid before them by King Charles II, drawn and prepared by that incomparable Architect Sir Christopher Wren, of rendering the whole City regular, uniform, convenient, durable and beautiful without any Man's loss, or infringement of any Propoerty. The City would then have been buit in such a manner, as

\footnotetext{
32 cited by McKellar The Birth p.90

${ }^{33}$ Defoe $A$ Tour; Konvitz Cities \& the Sea p.12
} 
to have stood foremost at this day amongst the Wonders of the World, for Extent, Symetry, Commodiousness and Duration, at much less Expense than the Citizens have been at in Rebuilding it in the confused irregular and perishable Manner tis now left in.' 34

James Ralph's Critical Review of the Publick Buildings, Statues and Ornaments in and about London and Westminster, published in 1734, repeated the assertion that Wren's plan, a design that would have made London the wonder of the world, had been scotched by 'the Hurry of Rebuilding and Disputes about Property'.

The legend was enhanced by the appearance in 1750 of Parentalia, a family history written by Christopher Wren, son of the architect, and published by his grandson, Stephen Wren. When the Wren Society republished Parentalia in 1934 the editors expressed grave caution about its 'doubtful authority'. ${ }^{35}$ The most serious misrepresentation was its assertion that Wren's scheme had been approved by King and Parliament, and blocked only by the 'obstinate averseness on the greater part of the citizens to alter their old properties', notwithstanding that

'the Practicability of this whole Scheme, without Loss to any Man or Inffringement of any property, was at that time demonstrated, and all material Objections fully weigh'd and answered' . 36

The legend continued to gather momentum through the eighteenth century. When the family sold off Wren's drawings the original London plan was bought by the

\footnotetext{
${ }^{34}$ Hawksmoor Remarks p.11. See Hart Nicholas Hawksmoor ch.9

${ }^{35}$ Wren Society vol.XIV (1937) p.X

${ }^{36}$ Wren Parentalia p.269; Tinniswood Permission of Heaven p.158
} 
architect John Gwynn - designer of Magdalen Bridge, Oxford, and a friend of Samuel Johnson. In 1949 he published a fresh engraving which combined the 1666 plan with a transcript of Wren's original accompanying report, and two dense panels of text setting out his own theory of city planning. ${ }^{37} \mathrm{~A}$ city cannot amend its topographical Situation but can and should improve its Disposition, 'which embraces all ye Requisites of Light, Air, Cleanliness and Safety'. The only remedy for London's nuisances must be 'a well disposed plan of ye whole capital, divided into proper districts and put under the inspection of fit Persons by Authority'. Gwynn repeated the historically incorrect assertion that such a plan had been approved by King and Parliament in 1666 before being undermined by factional interests. 38

A powerful engraving of London before and after the disaster of 1666, published in 1756 by John Rocque, included the plan under the simple banner 'Showing the CITY after the Fire, Design'd by that Great Architect Sr Christophr Wren and approv'd of by King and Parliament but unhappily Defeated by FACTION'. ${ }^{39}$ John Gwynn returned to the myth of Wren's plan in 1766 when publishing his own London and Westminster Improved, timed to coincide with the centenary of the Great Fire, and dedicated to King George III. ${ }^{40}$ Again, France provided the reference point: he proposed to transform London into a new Paris with

\footnotetext{
37 Ogborn "Designs on the City" p.26

${ }^{38}$ Reddaway Rebuilding of London pp.312-2

${ }^{39}$ Rocque City after the Fire

${ }^{40}$ Ogborn "Designs on the City"pp.27-29
} 
boulevards, squares and ample quays. ${ }^{41}$ And the cautionary precedent, of course, was

'the unaccountable treatment the noble plan of Sir Christopher Wren met from the interested views of ignorant, obstinate, designing men (notwithstanding it had the sanction of King and Parliament) who by rejecting it did an irreparable injury to the City of London'. ${ }^{42}$

The Nineteenth Century - the Myth takes Wings

'Unhappily defeated by faction' - the charge was repeated and embellished by Wren's first nineteenth century biographer. James Elmes published the Memoirs of the Life and Works of Sir Christopher Wren on the centenary of the architect's death in 1823. As architect to the Port of London he took particular interest in the abortive proposal to erect public quays along the Thames waterfront in the manner of Paris and Bordeaux. ${ }^{3}$ Once Parentalia's tendentious account had been endorsed by Elmes it was even more often cited as an object lesson and invoked in support of the causes of the day. Among the historical bricoleurs who used Wren were public health reformers, municipalists and advocates of town planning.

Sanitarianism was one of the earliest and most effective of the single-issue reform movements that played an increasingly important part in nineteenth century

\footnotetext{
${ }^{41}$ Rosenau Social Purpose pp.38-41

${ }^{42}$ Morris History of Urban Form p.220

43 Jones "James Elmes"; Konvitz Cities and the Sea
} 
political life. Its goal was to improve public health and the means, given the prevailing medical theory that disease was caused by miasmas, involved both provision below-ground of pipework for water supply and water-borne sewerage and removal of above-ground obstacles to free ventilation. ${ }^{44}$ Both incurred resistance from vested interests. The story of Sir Christopher Wren's frustrated vision for post-Fire reconstruction offered a powerful historical parable and was much cited. Britain's most prominent advocate of public health was Sir Edwin Chadwick, secretary to the Poor Law Commission. ${ }^{45}$ In the best Utilitarian fashion this colleague of Jeremy Bentham made a statitical calculation that the rejection of the Wren plan had cost each succeeding generation 'a death rate too high by one third'. ${ }^{46}$ Shortly before his death in 1872 Chadwick was due to present a paper to the Royal Society of Arts on 'what engineering and architectural art, under the guidance of sanitary science, could do for the building of new cities and the rebuilding of old ones'. As a visual aid he commissioned from the illustrator Worthington G Smith a three dimensional bird's-eye rendering of London as it might have been. It was posthumously reproduced as a fold-out image in The Builder (figure 5) in order 'to show what Wren's diagonal lines would have done for external ventilation'.47

\footnotetext{
44 Hebbert "City in good shape"pp.434-7

45 Inwood History of London pp.421-7

46 Lewis Edwin Chadwick p.52

47 Richardson \& Thorne The Builder p.587
} 


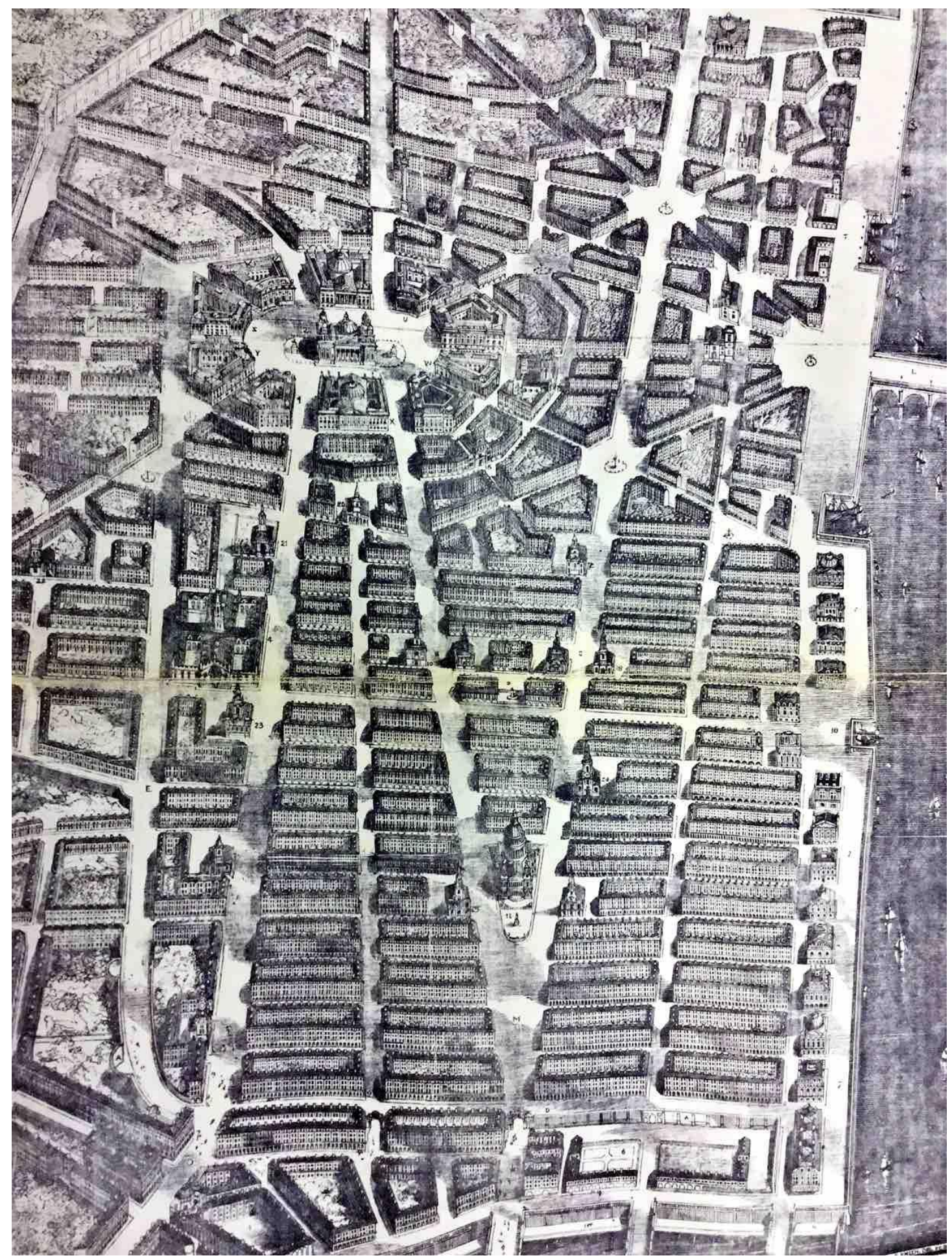

Fig.5 "A Vision of the City of London Constructed on the Plan left by Sir Christopher Wren" The Builder XXXIII (1875),1691,pp.598-9. Photo credit: author.

Two decades later Sir John Simon recapitulated the significance of the scheme in his book English Sanitary Institutions (1890), adding a distinctive late-Victorian twist of aversion to the decadent Stuart dynasty : 
'the largeness of [Wren's] proposal was beyond his contemporaries. To such pursekeepers as saw little beyond the moment and cared only to escape immediate outlay, the proposal seemed extravagent: and at that particular time - (just when the worthless dirty reign of Charles II was bringing on his subjects some of their worst humiliations) - even largerminded citizens might arguably not have had much heart to spare for local questions of commodiousness and adornment'. ${ }^{48}$

The precedent of the Wren plan continued to be cited in public health texts. In Health of the City (1910) Godfrey Hollis of the London School of Hygiene and Tropical Medicine presented it as thoroughly modern in its combination of zoning (removal of industry outside the City walls), provision of garden space, and hierarchical highway design, with traffic thoroughfares separated from residential streets. 49

Another recurring policy topic was local government reform. Reformers were exasperated by the resistance of the City of London to any sort of municipal modernisation to match the scale and challenges of the world's largest and fastgrowing city. ${ }^{50}$ Sir Walter Besant blamed the supine, decadent Stuarts failing to seize their chance of reform. ${ }^{51}$ They had let the City Corporation entrench itself within its historic privileges regardless of the problems of governance beyond its limits. Not until 1889 did Londoners have the chance to vote for a general metropolitan authority, the London County Council. Its first clerk Sir Lawrence

\footnotetext{
48 Simon Sanitary Institutions p.102

49 Hollis Health of the City pp.276-7

50 White London in the Nineteenth Century

51 Besant London p.281
} 
Gomme claimed a direct lineage in the aspiration for democratic self-government stretching back to Roman times, despite the encroachments of a decadent monarchy on the one hand, and a corrupt and self-serving City Corporation on the other. Here too the aftermath of 1666 took a symbolic status. In Gomme's perspective

'Wren's town planning scheme was a great effort. It remains as a London ideal - one of many London ideals to which London has not responded. John Evelyn too had a scheme - and these two Londoners of the decadent age did their best for the city'. 52

Between the narrow egotism of the City and the absolutist 'Wee' of Stuart kingship, Wren's efforts came to nothing. ${ }^{53}$ Gomme illustrated the iconic plan with the message that his LCC, as a modern metropolitan government, could accomplish improvements that in an earlier age had been thwarted by court and city. Similarly Wren's plan had formed the frontispiece of Percy Edwards's History of London Street Improvements 1855-1897. This detailed administrative narrative of Victorian highway projects, written by the Clerk of the LCC Improvements Committee, opened with a historical nod to that 'excellent plan ... set aside by the perverse self interest of the then citizens of London'. 54

No group of reformers drew more inspiration from the Wren model than town planners. The story of London's iconic plan and its defeat by faction became embedded in the foundation myth of the emergent profession. The first textbook

\footnotetext{
52 Gomme London p.257

53 Gomme London p.271

54 Edwards Street Improvements p.9
} 
to be published in Britain was Raymond Unwin's Town Planning in Practice (1909). It ran through eight editions in just over twenty years, with translations into German (1922), French (1924) and Russian (1925). Unwin reproduced Wren's plan, as redrawn by Reginald Blomfield for the History of Renaissance Architecture in England, and quoted verbatim and at length from James Elmes's biography, which in turn relied on Parentalia's image of a planner 'confined and cramped in his designs'. He praised the scheme 'alike for the masterly grasp of the problems to be dealt with and for the variety in the alignment and treatment'. 55 Similar homage reappeared in every subsequent planning text: Henry Aldridge's Case for Town Planning 56, Patrick Abercrombie's Town and Country Planning 57, Thomas Adams's Outline of Town \& Country Planning - a review of past efforts and modern aims. ${ }^{58}$ As late as 1961 Lewis Mumford's City in History could repeat the legend of a masterly Baroque scheme 'foiled by tenacious mercantile habits and jealous property rights'. 59

During the Second World War, when bombing devastated 225 acres of the City of London, (cf. 437 acres in 1666) the precedent of the wasted opportunities in the aftermath of the Great Fire was often invoked. A leading article in The Times warned of the danger that 'future Londononers will say of this generation what we say of the generation after the Great Fire - that it let London down'. 60 The 1945 book How Shall We Rebuild London ? by the garden city activist C.B.Purdom

\footnotetext{
55 Unwin Town Planning in Practice pp. 77-80

${ }^{56}$ Aldridge Case for Town Planning pp. 56-60

${ }^{57}$ Abercrombie Town \& Country Planning p.59

58 Adams Outline pp107-9

${ }^{59}$ Mumford City in History p.442

${ }^{60}$ Gibbon Reconstruction pp.256-7
} 
included a powerful illustration by 'Batt' - the pseudonym of artist and violinist Oswald Barrett - in which a giant-sized ghost of Sir Christopher Wren rises above a huddle of speculative builders and an intoxicated developer sipping profit from the city (figure 6). Wren's left hand points towards London ablaze, his right holds up a scroll inscribed 'Warning of 1666'. Purdom's text and appendix acknowledged that the means were lacking to implement such a vision in the seventeenth century but accepted no such impediment in the twentieth. 61

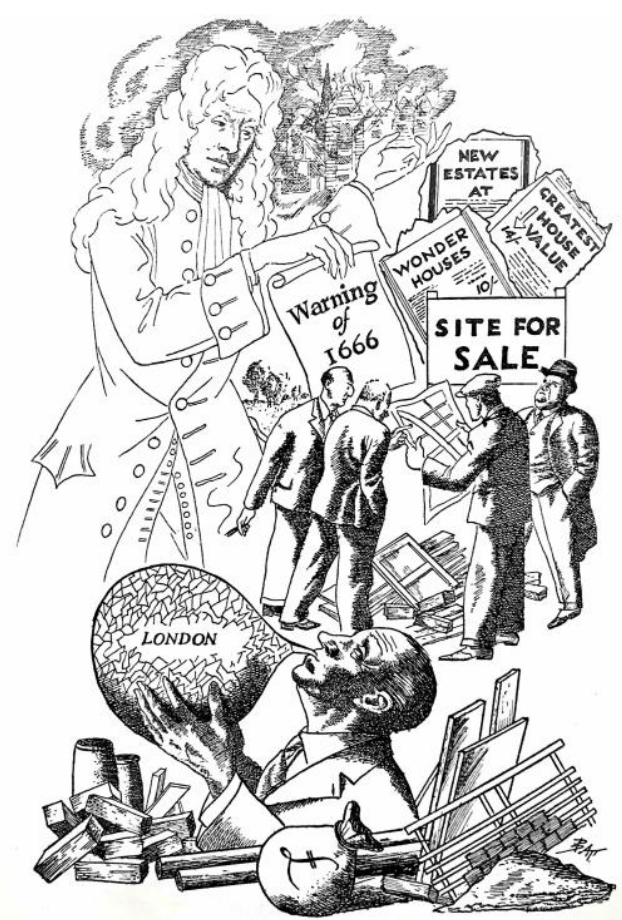

fig.6 'Exploitation' by BATT. From Purdom How Shall We Rebuild ? p.108. Photo credit: author

Perhaps the most remarkable testimony to Wren's warning was supplied by the City of London Chief Engineer's official report on the wartime destructions. It opened defensively with a reproduction of the 1666 master plan and a detailed apology, referenced with footnotes and an appendix, against the accusation of 'lost opportunity'. Never has a distant episode in planning history touched such a

${ }^{61}$ Purdon How Shall We Rebuild ? pp.148, 267 
political nerve. The City Corporation had wanted to pursue selective road improvements and piecemeal redevelopment in a context where planners of every persuasion, from the traditionalists around Sir Edwin Lutyens to the avant-garde of MARS, the Modern Architecture Research Group, demanded comprehensive renewal.62 In vain the Improvements \& Town Planning Committee pointed to the millions of pounds' worth of infrastructure embedded within the existing street plan and protested against the habit of regarding bomb-damaged areas 'as virgin land, upon a blank plan of which the pencil of a planner ... can freely or fancifully travel'.63 Such assertions failed to allay suspicion that the City Corporation was once again sacificing long-term vision to short-term commercial interest. In the summer of 1945 the Minister of Town \& Country Planning - the Conservative Arthur Greenwood - wrote to warn the City that he would have the greatest difficulty in approving their Engineer's plan. His letter included a reminder (as Sir Frederic Osborn reported delightedly to Lewis Mumford) that the City of London had lost a great opportunity in 1666 and must not lose this greater one.64 The City were obliged to seek the advice of consultants. Sir Charles Holden and Sir William Holford were duly appointed: their report was presented in 1947 and published in book form as The City of London: a Record of Destruction and Survival. Once again, twentieth century proposals were framed within a detailed discussion of rebuilding in the aftermath of the Great Fire. Holden and Holford took Wren as their starting point, 65 invoking his memory in support of extensive highway proposals, and the creation of a vast ceremonial place and processional way up

\footnotetext{
${ }^{62}$ Cherry \& Penny Holford p.136

${ }^{63}$ Corporation of London Reconstruction p. 2

${ }^{64}$ Hughes ed Mumford \& Osborn p.95

${ }^{65}$ Corporation of London City of London p.153
} 
Ludgate Hill from Fleet Street to the west facade of St Paul's Cathedral (figure 7).

More of that later.

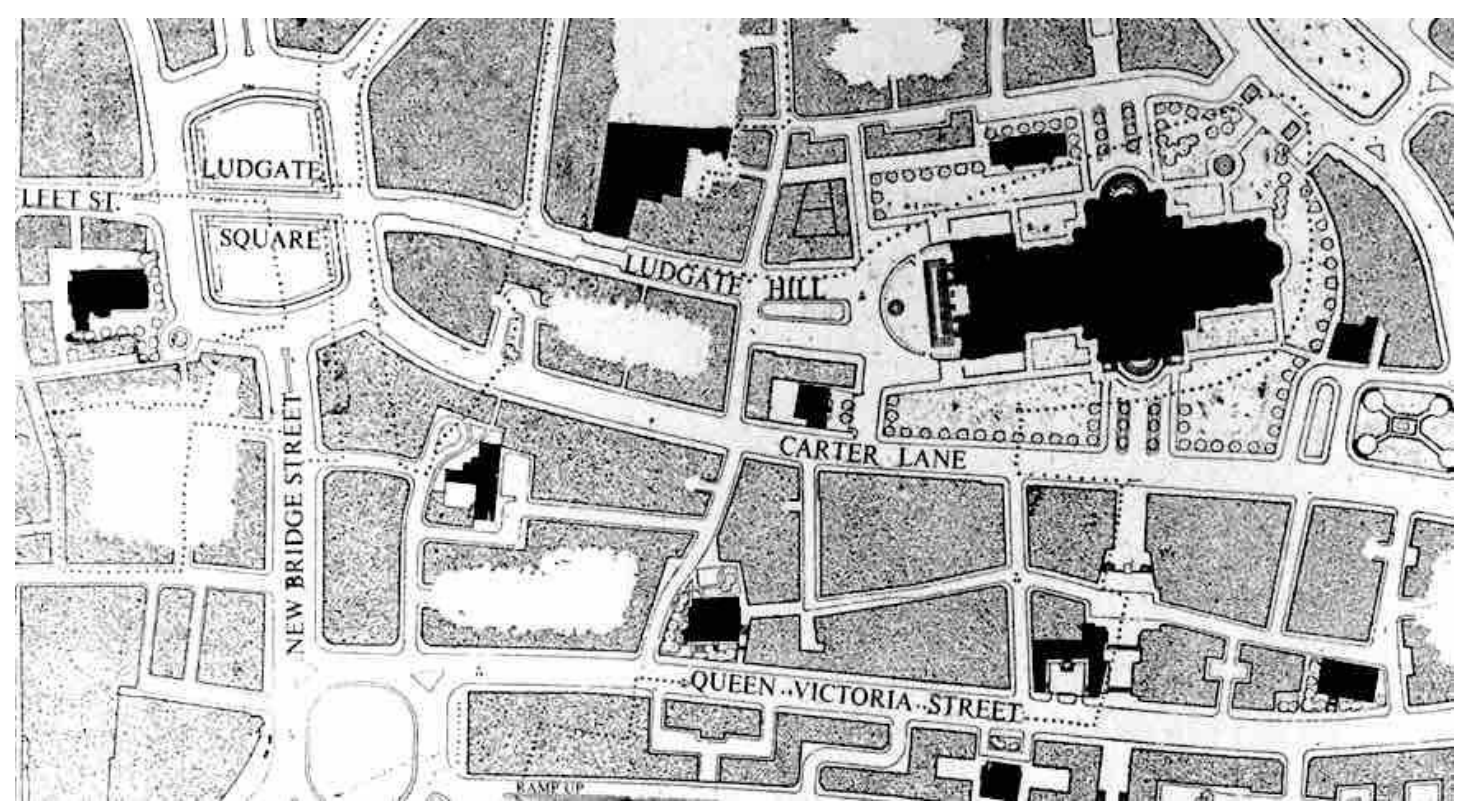

fig 7 Ludgate Hill processional route, as proposed by Charles Holden and William Holford after WW2. From Corporation of London City of London. Photo credit: author

Historical interpretation is dialectical. The essence of its method is a continuous testing of narratives against the evidence. Any received wisdom will sooner or later come under scrutiny. In the case of the Wren plan, the revisionist challenge happened to coincide with the mid-twentieth-century apogee of the myth. Its alternative reading of history - an equally potent myth - is explained in the following section. The paper concludes with a case study of the development site that became celebrated as a battle ground for these ideas.

\section{Revisionism}

For his 1920 book The Great Fire of London in 1666 the London historian Walter G. Bell prepared a fascinating map in which Wren's proposed design, in blue, is overlaid on the pre-Fire street plan, in black (figure 3 above). There is no 
correspondence whatsoever between the two sets of lines. The map reveals at a glance 'how completely the great scientist would have destroyed the City as today we know it and as it has come to us by the growth of centuries'. ${ }^{66}$ This insight was developed by the Danish architectural historian Steen Eiler Rasmussen into a radically different perspective on Wren's role. Wren was well versed in the genre of Renaissance ideal city plans. His drawing - 'a rather abstract product of a great intellect' - offered an ideal-type mathematical solution to the geometrical problem of linking a limited number of fixed points - the City gates, the Royal Exchange, the Cathedral and London Bridge. 67 It was intellectually elegant rather than practicable: 'a beautiful pattern of streets which a clever man can design in a day or two'. ${ }^{68}$ Rasmussen deftly turned conventional wisdom on its head:

'From our point of view the rejection of Wren's plan is not a fault but rather a new triumph for what might be called the idea of London' 69

He pinpointed King Charles II's proclamation of September 13th 1666 with its 'upon the whole astonishingly modern' proposals for scientific survey, mapping, regular street widths, compensation, independent arbitration by knowing and intelligent persons in buildings, fireproof building codes and reconstruction in situ: 'it is a true piece of town planning, a programme for the development of the town'. 70

\footnotetext{
${ }^{66}$ Bell Great Fire p.232

${ }^{67}$ Rasmussen London p.104

68 Rasmussen London p.112

${ }^{69}$ Rasmussen London p.113

${ }^{70}$ Rasmussen London p.116
} 
Rasmussen's revisionist perspective on the Great Fire, advanced within a larger morphological interpretation of London viz à viz other European metropolises, was based on perceptive reading of secondary literature. It soon received a powerful endorsement from the archival research of Thomas Fiddian Reddaway, published in timely fashion on the eve of the Blitz as The Rebuilding of London after the Great Fire. He demonstrated how, in the confused aftermath of 1666, the King had played a decisive role not as promoter of Baroque urbanism, but as facilitator of a utilitarian reconstruction that would reduce fire risk, rid the City of its spouting gutters, and ensure that thoroughfares were paved and passable: 'a citizen's city with none of the absolute monarch's inclination towards the grandiose'. ${ }^{71}$ Appendix A of Reddaway's book directly addressed and refuted the myth that Wren's plan had been approved by King and Parliament but defeated by faction.

The war-time publication of Reddaway's research ensured a place for the revisionist perspective in the debate about rebuilding. Sir Gwilym Gibbon's 1942 book Reconstruction dismissed the Wren plan as 'not more than the dream of a brilliant amateur' - 'a grandiose scheme, much inflenced by what he had seen and learned of foreign developments not native to the soil'. ${ }^{72}$ John Summerson's Georgian London, published just after the war, reached a similar verdict. ${ }^{73}$ Though postwar town planning texts continued to reproduce the myth of Wren's plan, the scholarly mainstream followed Rasmussen. The grand design shrank in

\footnotetext{
${ }^{71}$ Reddaway Rebuilding of London p.298

72 Gibbon Reconstruction pp.253-4

${ }^{73}$ see note 16 above
} 
estimation to 'an overnight exercise based on the use of undigested continental Renaissance plan motifs' ${ }^{74}$. As Adrian Tinniswood observes, such disparagement went too far. ${ }^{75}$ Unimplementable it may have been, yet the exquisite drawing in the Codrington Library (figure 8) remains a milestone in the history of European urbanism.

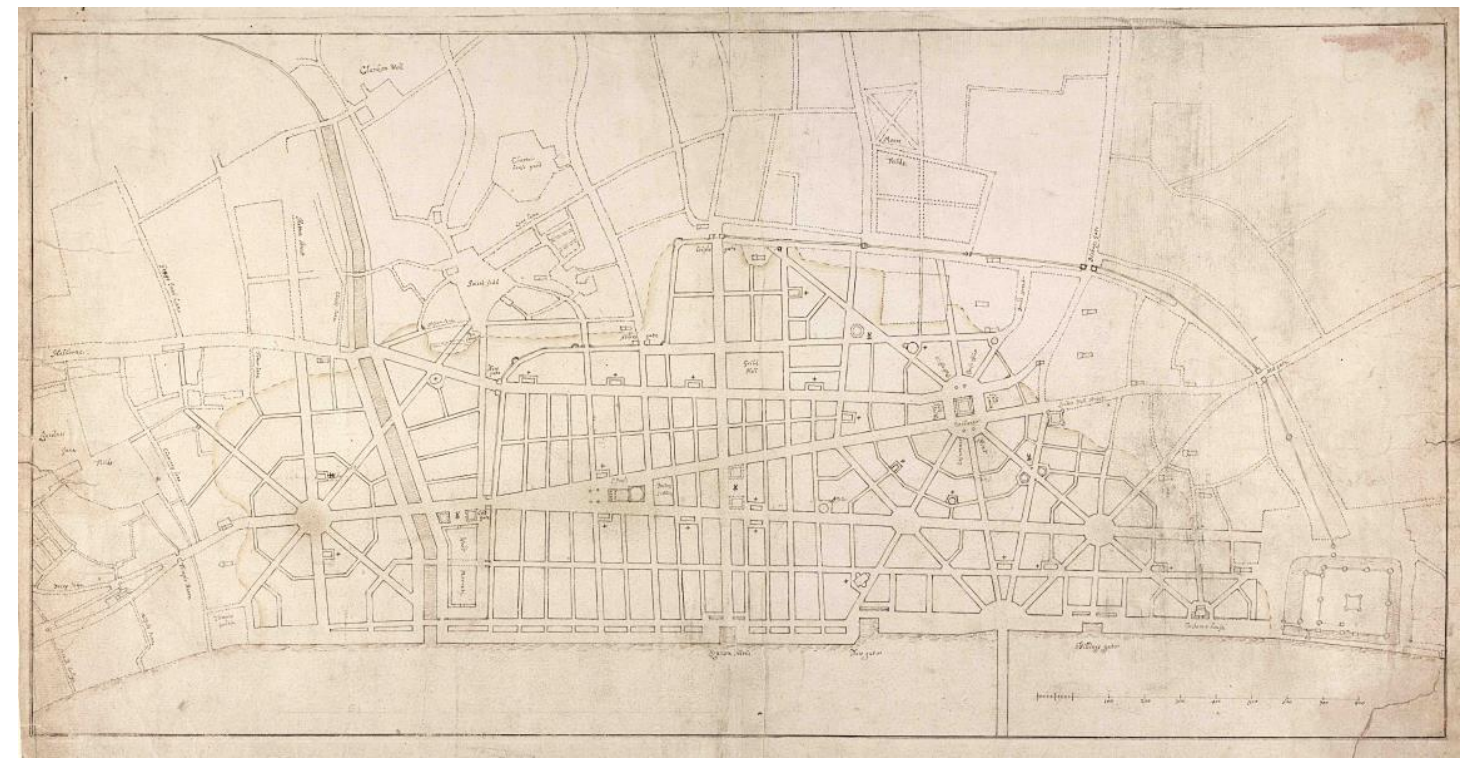

Fig. 8 The original drawing (Wren 1.7) in the Codrington Library, All Souls College, Oxford. Digital reproduction by kind permission of the Warden \& Fellows of All Souls College.

Nevertheless, recent London historiography follows Rasmussen's that the city owes more to the shaping power of regulation and localised management than large-scale design. ${ }^{76}$ Donald Olsen's Town Planning in London (1964) was a classic of the genre in its detailed analysis of the development and management of the Bedford and Foundling Hospital estates. In his introduction to the second edition, Olsen recalled how his book had been regarded as an attack of a shibboleth of the planning movement, being bracketed with Jane Jacobs's subversive Death and Life

\footnotetext{
74 Morris Urban Form p.220

${ }^{75}$ Tinniswood His Invention so Fertile p.159

${ }^{76}$ Hebbert More by Fortune
} 
of Great American Cities for daring to suggest that a city without centralised vision or grand design might be satisfactorily developed through a patchwork of landlord promoters and leasehold management. ${ }^{77}$

The revisionist reading of London's planning history emphasized what Cruikshank and Wyld call the 'orderly flexibility' of architectural classicism under the London Building Acts. ${ }^{78}$ Elizabeth McKellar's investigation of speculative building processes in The Birth of Modern London showed how the 1667 Rebuilding Act formalised the Puritan minimalism of plain brick houses in simplified classical style, vertical in form, joined in terraces, with party walls for fire safety. ${ }^{79}$ Though its legal provisions applied (at first) only to the square mile of the City, its influence was generic. The regulatory provisions of the Act formed the template for an entire mode of building production based on precise ground plans rather than 'uprights' or elevations. Plan dimensions generated valuations and contracts for artificers, according to principles set out by William Leybourn and Joseph Moxon. Andrew Saint describes the result as a city that is 'regularly irregular', planned in the passive rather than the active sense, 'a specifically English model of urbanism, perhaps the only fair one in a mercantile democracy, where power is balanced in subtle ways, and the great hidden interests in urban development are those of trade, property and common law'. 80

\footnotetext{
77 Olsen Town Planning pp.2-3

${ }^{78}$ Cruikshank \& Wyld London pp.21-32

${ }^{79}$ McKellar The Birth; see also Mowl \& Earnshaw Architecture Without Kings

80 Saint "Grand Designs" p.49
} 


\section{Wren's Legacy Reconsidered}

The revisionist perspective puts Christopher Wren's urban achievement in a fresh light. Having already been involved with St Paul's Cathedral before the Great Fire, he insisted on the need to demolish what remained of the mediaeval Gothic nave and build afresh the mighty structure we have today. In the immediate aftermath of the Fire he proposed the same approach for the many City churches lost in the blaze. A strange feature of his abortive master-plan was their replacement with a new set of ecclesiastical buildings parked in geometrical order along the principal thoroughfares. The impossibility of redrawing from scratch the intricate patchwork of parishes no doubt contributed to the prompt rejection of the plan, and opened up for Wren the alternative challenge of designing new churches in seventeenth century classical idiom within the tight constraints of a mediaeval site plan.

He succeeded triumphantly. No fewer than fifty-one of the City's parish churches were rebuilt on their original sites. As Elizabeth and Wayland Young observed in London's Churches, Wren's practical and empirical genius was shown to greatest advantage in the way he made a virtue of necessities 'like the great Gothic builders before him'. ${ }^{81}$ Funding from the tax on coal enabled him to adorn each church with a tower or steeple of white Portland stone, varying the designs of spires and lanterns from parish to parish around the mighty silhouette of the cathedral. London's historic skyline - most famously painted by Canaletto - revealed the subtle relationship between the churches and the dome of St Paul's, all the work

${ }^{81}$ Young \& Young London's Churches p.10 
of a single hand. Peter Burman rates it as ' a concept of artistic unity in design possibly without parallel in the whole history of European architecture'. ${ }^{82}$ In the Youngs' words :-

'It is this huge concept, this panoramic balancing of the shape, texture, colour and distances of the dome and the steeples of London which makes Wren one of the supreme artists. Here the professor of astronomy built his own solar system of white stone, black lead and sometimes crystal air'. 83

Seen from afar, Wren's skyline was a wonder of the world - in the opening phrase of William Wordsworth's poem Composed upon Westminster Bridge, September 3rd 1802, 'Earth has not anything to show more fair'. But equally remarkable, and more germane to our topic, was the skill with which each church was planned in relation to its site. As Nicolas Taylor once observed, Wren was in his way a pioneer of the picturesque. ${ }^{84} \mathrm{He}$ used the irregular street pattern to conceal, reveal and frame his brilliant new churches, 'alive with lines, shapes and silhouettes of masterly conception and infinite variety'. ${ }^{85}$ Though twentieth century development has destroyed the skyline and broken up the street plan, the picturesque qualities of these buildings is very evident in the old photographs of the City compiled by Colin Amery ${ }^{86}$ or in the long tradition of charcoal, ink or watercolour sketches made in the streets of London (e.g. figure 9).

\footnotetext{
82 SPAB Save the City p.142

${ }^{83}$ Young London's Churches p.11

${ }^{84}$ Taylor Awful Sublimity p.433

85 Jones London Triumphant p.94

${ }^{86}$ Amery Wren's London
} 


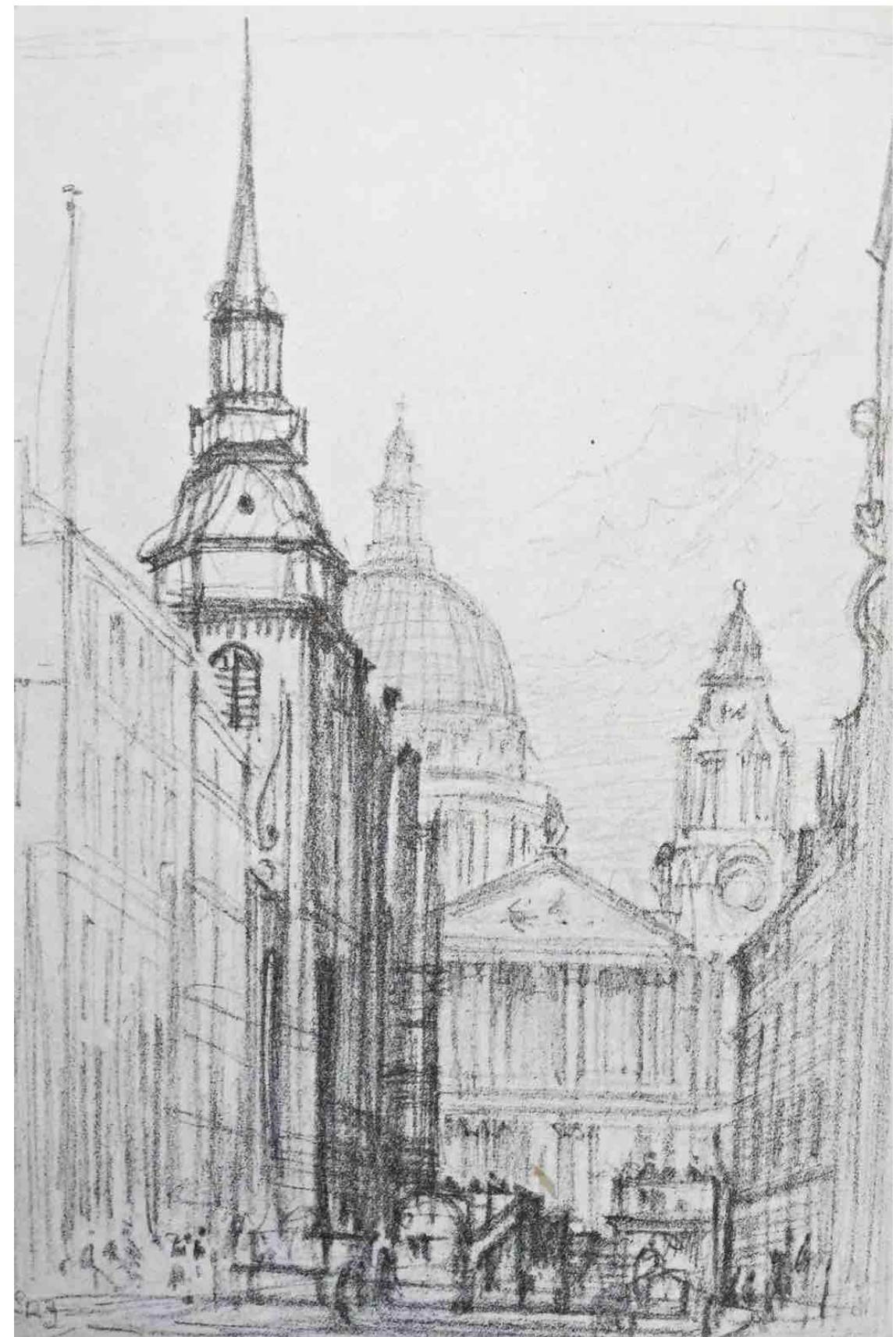

fig 9 St Paul's and St Martin Ludgate,1922. From Jones London Triumphant p.92. Photo credit: author

Consquently war-time bombing posed a puzzle for reconstruction. Should streets be rebuilt on their old irregular alignments or widened to open up views ? Either strategy might claim endorsement from Sir Christopher Wren. The conflict was most apparent just north of St Paul's in the triangular district around Paternoster Square. After heavy bombing, the site was designated a Comprehensive 
Development Areas and cleared for renewal. Sir William Holford secured the coveted commission. As he explained to the Minister's advisory committee, the choice was between 'Formal' or 'Informal' approaches. His first design was Formal, echoing the Wren plan with a ceremonial axis up Ludgate Hill. ${ }^{87}$ But after several taxing sessions with a wooden block model in the office of the Minister, Duncan Sandys, informality prevailed and a squat office block, Juxon House, was built across the line of sight, screening the cathedral's entrance portico from view until revealed on the bend at the top of Ludgate Hill. ${ }^{88}$ What was intended as a subtle townscape effect, became notorious as a planning blunder and after only twenty years Holford's Paternoster Square was demolished and a competition held for its replacement. In a celebrated intervention the Prince of Wales attacked the initial proposals of signature architects such as Norman Foster, Arato Isozaki, Richard Rogers and James Stirling, urging instead the adoption of a scheme by John Simpson that would set St Paul's Cathedral in a frame of geometrically arranged classical buildings, as originally intended (so it was argued) by Christopher Wren.

But, as the architectural critic Gavin Stamp observed, Prince Charles's call for classical order was based on an erroneous reading of history. Despite its monumental scale Wren's architecture was intended for encounter in proximity, not in a setting of long spatial axes:

'. . what is required is an understanding that the traditional character of the City is not classical but irregular, intimate and picturesque because it is

${ }^{87}$ Cherry \& Penny Holford pp.161-162

${ }^{88}$ Cherry \& Penny Holford pp.164-174 
ultimately mediaeval. Wren failed to make London like baroque Rome and once his idealistic plan was rejected he came to terms with existing conditions and constraints. London was rebuilt on its mediaeval street patterns and the new St Paul's fits into this magnificently'. 89

The principle of morphological continuity was accepted as the basis of the scheme by Sir William Whitfield that provides the setting for St Paul's today. Half a century after its obliteration in the Blitz, Paternoster Square was reopened as a public space. Narrow streets once again frame glimpses of the cathedral [figure 10). Introducing a promotional booklet to celebrate the scheme's completion, the London novelist Peter Ackroyd rejoiced that a patch of the city had 'reverted to its old self':

'Here are shops and offices where mercers and publishers once worked, It is a miracle of resurrection in a city where such miracle do occasionally happen. After the Great Fire the old streets were rebuilt upon the same pattern. Now in Paternoster Square the shape of the old territory is being revived. It is as if London were some organic being with an underlying form of its own, a form that emerges even after the most catastrophic circumstances'. 90

\footnotetext{
${ }^{89}$ Stamp "By a City churchyard"p.13
}

90 Jackson Story of Paternoster p.4 


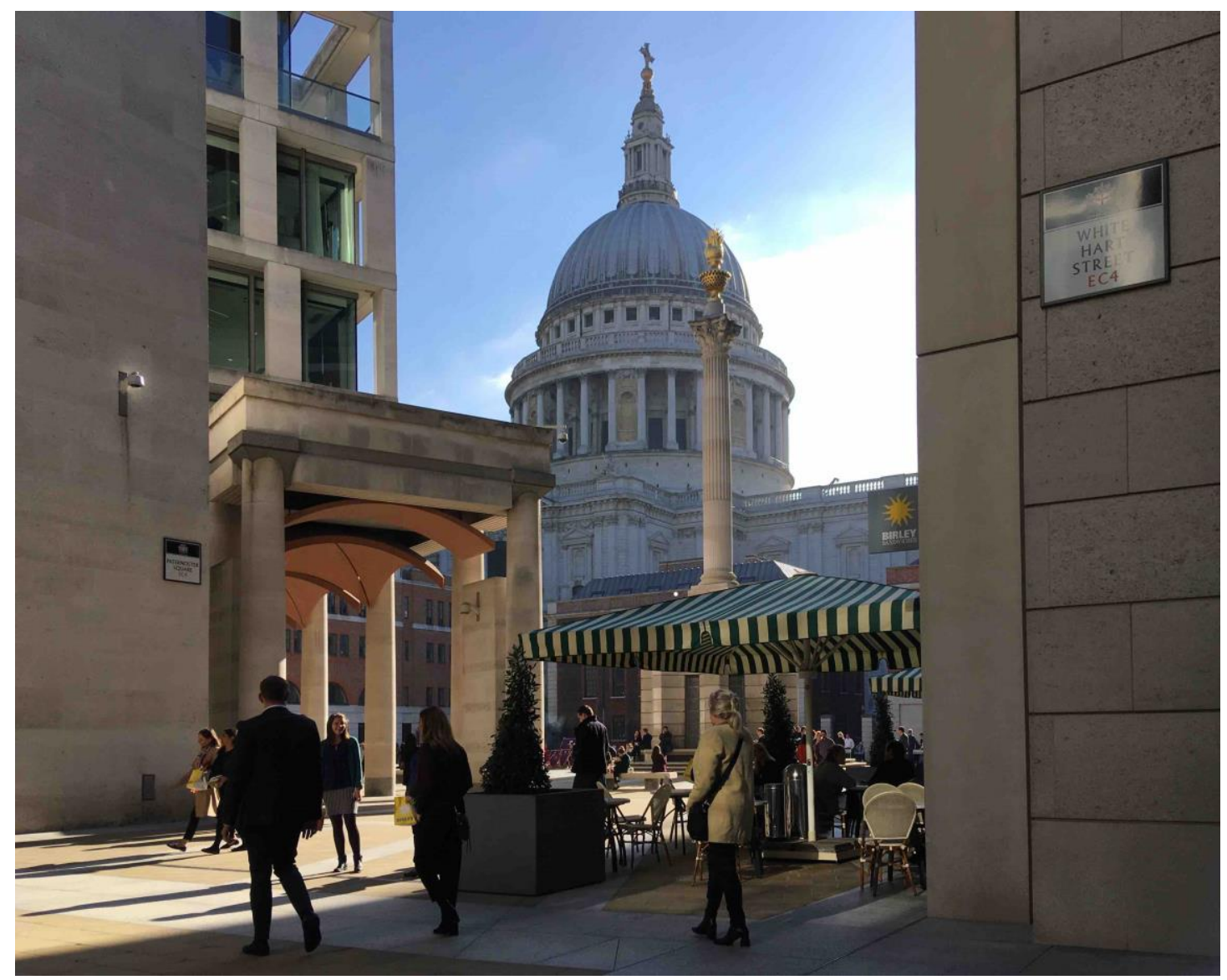

fig 10 View of St. Paul's from the corner of White Hart Street and Paternoster Square, late October 2018. Photo credit: author

\section{Conclusion}

One of the fascinating aspects of planning history is the persistence of plans. Lines once drawn on the map may acquire an agency that outlasts the circumstances of their creation. The Baroque vision for the City of London that Christopher Wren presented to King Charles II on September 10 th 1666 was a plan that, in the literal meaning of the word, became iconic. Over the passage of centuries the icon attracted the worship of many different groups: a layout conceived as expressing monarchical order in the context of the Stuart Restoration became construed as a pioneer of public health reform in Victorian England and a mythical precursor to the professional town planning of twentieth century. Common to all the iconic 
readings was a historical belief that Wren's plan had been approved and adopted as a collective vision before being foiled by commercial greed and jealousy.

Archival research corrected that error and opened the way for a different reading of London's planning history and more subtle appreciation of Sir Christopher Wren's contribution. Rejection of his Baroque master plan caused him 'to make a virtue of necessity and adapt his first ideas good humouredly when they did not suit'. ${ }^{91}$ It was this pragmatic genius that gave London its marvellous skyline of the dome of St Paul's and flotilla of church spires. Alas, the urban panorama painted by Canaletto and captured by Wordsworth was eroded by office blocks in the late twentieth century and - with the effective abandonment of building height control since the miliennium - has been utterly lost today. If planning historians want to see how the genius of Wren was, in John Gwynn's phrase, unaccountably betrayed by 'ignorant, obstinate, designing men' they would do better to look at London's skyline than its street plan.

\section{Acknowledgements}

The paper originated as the keynote lecture for the day conference The Great Fire Reconsidered held in the Wren Suite, St. Paul's Cathedral, on the 350th anniversary of the disaster, September 3rd 2016. With due thanks to Rebecca Rideal who provided the prompt to examine the planning history of Christopher Wren's 1666 plan, and to its present guardian Gaye Morgan, Librarian in Charge and Conservator, Codrington Library, All Souls College.

91 Young \& Young London's Churches p.10 


\section{Bibliography}

Abercrombie, Patrick. "Wren's Plan for London after the Great Fire" Town Planning Review 10 (1923) 2, 71-80

Adams, Thomas. Outline of Town and Country Planning - a review of past efforts and modern aims. New York: Russell Sage Foundation, 1935.

Adshead, Stanley D."Sir Christopher Wren and his Plan for London", pp.161-174 in Dircks R ed. Sir Christopher Wren 1632-1723. London, Hodder \& Stoughton, 1923.

Aldridge, Henry. The Case for Town Planning : a practical manual for the use of Councillor, Officers and others engaged in the preparation of Town Planning schemes. London, National Housing and Town Planning Council, 1915.

Amery, Colin. Wren's London. Luton, Lenard Publishing, 1988.

Bell, Walter G. The Great Fire of London in 1666. London, Bodley Head, 1920.

Besant, Sir Walter. London in the Time of the Stuarts. London, Adam \& Charles Black, 1903.

Burman, Peter. St. Paul's Cathedral. London, Bell \& Hyman, 1987.

Cherry, Gordon and Penny, Leith. Holford - a study in architecture, planning and civic design. London, Mansell, 1986.

Corporation of London. Reconstruction in the City of London. London, Batsford, 1944.

Cooper, Michael. 'A More Beautiful City': Robert Hooke and the Rebuilding of London after the Great Fire. Stroud, Stroud Publishing, 2003.

Corporation of London. The City of London : a Record of Destruction and Survival. London, Architectural Press, 1951.

Cruikshank, Dan \& Wyld P. London: the Art of Georgian Building. London, Architectural Press, 1975.

Defoe, Daniel. A Tour Through the Whole Island of Great Britain, [1724] Republished with introductions by G.D.H. Cole and D.C Browning. London, Dent, 1974.

Edwards, P. J . History of London Street Improvements 1855-1897. London: London County Council, 1898. 
Evelyn, John. London Revived: consideration for its rebuilding in 1666 edited by E S de Beer. Oxford: Clarendon Press, 1938.

Geraghty, Anthony. The Architectural Drawings of Sir Christopher Wren at All Souls College, Oxford: a complete catalogue. Aldershot: Lund Humphries, 2007.

Gibbon, Sir Gwilym. Reconstruction and Town and Country Planning. London, Architect \& Building News, 1942.

Gomme, Sir Laurence. London. London, Williams \& Norgate, 1914

Hart, Vaughan, Nicholas Hawksmoor - Rebuilding Ancient Wonders. New Haven and London, Yale University Press, 2002.

Hawksmoor, Nicholas. Remarks on the Founding and Carrying on of the Buildings of the Royal Hospital at Greenwich. London, N.Blandford, 1728.

Hebbert, Michael. London More by Fortune than Design. Chichester, Wiley, 1997.

Hebbert, Michael. "A City in Good Shape: town planning and public health" Town Planning Review, 70 (1999),4,433-453

Hebbert, Michael. "Figure-ground: history and practice of a planning technique". Town Planning Review, 87 (2016), 6, 705-728

Hibbert, Christopher. London; the Biography of a City, Revised Edition. London, Allen Lane, 1977.

Hollis, Godfrey. The Health of the City. Boston: Houghton Mifflin, 1910.

Hughes, Michael ed. The Letters of Lewis Mumford and Frederic J. Osborn - A Transatlantic Dialogue, 1938-1970. Bath, Adams \& Dart, 1971.

Hyde, Ralph ed. The A to Z of Restoration London. London: London Topographical Society, 1992

Inwood, Stephen. A History of London. London, Macmillan, 1998

Jackson, Nicola. The Story of Paternoster - A New Square for London. London:

Wordsearch for Mitsubishi Estate Co Ltd, 2003

Jardine, Lisa. On a Grander Scale: the outstanding career of Sir Christopher Wren. London, Harper Collins, 2002.

Jones, Sydney R. London Triumphant. London \& New York, Studio Publications, 1942. 
Jones, Tom Devonshire. "James Elmes 1782-1862, architect: from youthful editor to aged gospeller" British Art Journal X (2009), 2,67-72

Knowles C. C. and Pitt P.H. The History of Building Regulation in London 11891972. London, Architectural Press,1972.

Konvitz, Joseph W. Cities and the Sea: Port City Planning in Early Modern Europe. Baltimore, Johns Hopkins University Press, 1978.

Konvitz, Joseph W. The Urban Millenium: the city building process from the early middles ages to the present. Carbondale, South Illinois University Press, 1985.

Lewis, Richard Albert. Edwin Chadwick and the Public Health Movement 1832-54. London, Longmans Green, 1952

McKellar, Elizabeth. The Birth of Modern London : development and design of the city 1660-1720. Manchester, Manchester University Press, 1999.

Moore, John E. "The Monument, or, Christopher Wren's Roman Accent". The Art Bulletin 80 (1998), 3, 498-533

Morris, Arthur. History of Urban Form Before the Industrial Revolution. London, George Godwin Ltd., 1979.

Mowl, Tim and Earnshaw, Brian. Architecture without Kings: the rise of Puritan Classicism under Cromwell. Manchester, Manchester University Press, 1995.

Mumford, Lewis. The City in History. Harmondsworth, Penguin, 1961.

Muthesius, Stefan. The English Terraced House. New Haven : Yale University Press, 1982.

Ogborn, Miles. "Designs on the City: John Gwynn's Plans for Georgian London", Journal of British Studies 43. (2004) 1, 15-39

Olsen, Donald. Town Planning in London: the eighteenth and nineteenth centuries. New Haven, Yale University Press, 1982.

Purdom, C.B. How Shall We Rebuild London ? London, Dent \& Sons, 1945.

Ralph, James. Critical Review of the Publick Buildings, Statues and Ornaments in and about London and Westminster, to which is prefix'd, the dimensions of St. Peter's Church at Rome and St Paul's Cathedral at London. London, J. Wilford, 1734.

Reddaway, Thomas F. The Rebuilding of London after the Great Fire. London, Jonathan Cape, 1940. 
Richardson, Ruth and Thorne, Robert. The Builder Illustrations Index 1843-1883. London, Hutton and Rostron for Institute of Historical Research, 1994

Robinson, J. H. "Sir Frederick Trench and London Improvements". History Today, 27 (1977), 5, 3, 324-331

Rocque, John. Map Showing the CITY after the Fire. . 1756. Available online at http://www.bl.uk/onlinegallery/onlineex/crace/a/largeimage88331.htm l

Rosenau, Helen. Social Purpose in Architecture: Paris and London Compared 17601800. London, Studio Vista, 1970.

Saint, Andrew. "Grand Designs on London". Architectural Journal, 194 (1991), $24 / 5,46-55$

Saunders, Anne ed. The A to Z of Charles II's London 1682 . . Actually Surveyed by William Morgan. London, London Topographical Society, 2013.

Simon, Sir John. English Sanitary Institutions - Reviewed in their Course of Development and in Some of their Political and Social Relations London, Cassell, 1890.

SPAB. Save the City - a Conservation Study of the City of London. [by a Joint Committee of SPAB, Georgian Group, Victorian Society \& Civic Trust]. London, Society for the Protection of Ancient Buildings, 1976.

Summerson, John. Georgian London. London, Pleiades, 1945.

Stamp, Gavin. "By a City Churchyard" Spectator August 21st, 1987

Stewart, Cecil. A Prospect of Cities. London, Longmans, 1952.

Taylor, Nicholas. "The Awful Sublimity of the Victorian City". pp.431-447 in vol.2 of H.J.Dyos and Michael Wolff eds. The Victorian City - Images and Realities. London, Routledge \& Kegan Paul, 1973.

Tinniswood, Adrian. His Invention so Fertile - a Life of Christopher Wren. London, Jonathan Cape, 2001.

Tinniswood, A. By Permission of Heaven: the Story of the Great Fire of London. London, Jonathan Cape, 2003.

Uglow, Jenny. A Gambling Man: Charles II and the Restoration. London, Faber \& Faber, 2009.

Unwin, Raymond. Town Planning in Practice - an Introduction to the Art of Designing Cities and Suburbs. London, T. Fisher Unwin, 1909. 
Upcott, William, ed. The Miscellaneous Writings of John Evelyn. London, Colburn, 1825.

White, Jerry. London in the Nineteenth Century: a human awful wonder of God. London, Vintgae, 2008.

Wren, Christopher. Parentalia (first published by Stephen Wren, 1750. Brill, E. J. Enthoven, 1903. Available online, DOI: 10.3931/e-rara-10334

Wren Society. The Wren Society. Edited by Bolton A. T. and Hendry H. D. in 20 volumes. Oxford, Oxford University Press, 1924-1943.

Young, Elizabeth and Wayland. London's Churches. London, Grafton Books, 1986. 
